alike upon all the seats of mental operations, but that there is a partial suspension of action of the higher faculties, such as reason and will, while there is an irritable excess of action of the seats of the more elementary faculties, such as the conception of ideas, etc., which is exhibited either by excessive rapidity of succession of ideas or undue impressions of single ideas." Dr. D. H. Tuke, in his presidential address (1881), has pointed out that this doctrine of Dr. Monro's is a still clearer statement of the theory that insanity is caused by the depression or paralysis of the higher nervous centres and excessive action of others, a doctrine which $\nu$ r. Hughlings Jackson has adopted and extended, applying to it the hypothesis of evolution and dissolution as enunciated by Herbert Spencer. Insanity, according to this view, is dissolution beginning at the highest cerebral centres, the dissolution being either uniform or partial, and also varying in "depth," and Dr. Tuke further remarks in his work on "Sleep-Walking and Hypnotism" that the doctrine of positive and negative states of Dr. Monro is even more applicalle to the changes. involved in dreaming and sleep-walking, these being a physiological liberation of energy of one portion or centre of the brain, and a persisting stability of another part which, freed from control, may come into active play (p. 7). The whole of this treatise by Dr. Monro is characterized by thoughtful observation, as is an article published by him in the second volume of our Journal on the Nomenclature of the various forms of insanity. Among other topics he gives a good account of so-called " acute dementia," to which other names have been assigned by different writers. He proposed the name of cataleptoid insanity, "the symptoms bearing a striking resemblance in some points of view to catalepsy.'

Dr. Monro was a regular attendant at the meetings of the Fellows at the College of Physicians, where in 1861 he had filled the office of Censor, and in other years that of Councillor. He was greatly interested also in the various Lunacy Bills which were for so many years before the legislature, and a diligent attendant at committees thereon. His genial and kindly nature brought him many friends in both Houses, and their advice was of much assistance at this period. But beyond professional interests he had a great and never failing delight in art, which he inherited from his grandfather and great-grandfather and he was rarely absent from Christie's when an important sale of pictures was taking place. His taste and judgment here were excellent, and he was no mean artist himself, as the portraits executed by him at the College sufficiently testify. Though latterly he had somewhat failed in strength, yet a few years ago he looked singularly youthful for his age, and no one would have supposed that he had seen seventy years. Among his sons he leaves none, we regret to say, in the profession to carry on the line of psychological physicians,

G. F. BLANDFORD.

\title{
H. G. SUTTON, M.D.
}

We have to record the death of a very old member of our Association, one ill spared from general and special medicine; we refer to Dr. H. G. Sutton physician to the London Hospital. He, with Dr. Hughlings Jackson, more than 25 years ago began to distinguish himself as a pathologist.

He did very excellent work in showing how few of the so-called local diseases were really local, they were but local manifestations of general pathological states. He pointed out that in such a disease as Bright's not only was the kidney tissue affected, but that there were widespread changes involving the nervous tissues as well. Dr. Sutton was a man of the widest sympathies, and always had a strong liking for affections of the mind and their rational treatment. He was not only a physician but a refined man, who believed in the value of outside culture for the hard-working physician, he himself spending much of his leisure in the study and practice of musio and of art. Deeply 
sympathetic, a devout man without any sectarian narrowness, he worshipped more often in the temple of nature than in that of ohurches. He longed for the rest which he has now found.

\section{RICHARD GUNDRY, M.D., MEDICAL SUPERINTENDENT OF THF} SPRING GROVE ASYLUM, MARYLAND, U.S.A.

Dr. Gundry was born in 1830 , at Hampstead Heath. When thirteen years of age he accompanied his father, the Rev. Jonathan Gundry, who was a Unitarian Minister, to Canada, and commenced the study of medicine at Simcoe, Ontario. He ultimately graduated at the Harvard Medical School, where he carried off the first prize. After a tour through Europe he commenced practice in Columbus, Ohio, and was then appointed second assistant physician in the Columbus Hospital for the Insane. He also held the post of Professor of Materia Medica and Mental Diseases in the Starling Medical College, Columbus. In 1858 he was transferred to the Ohio Insane Asylum at Dayton, and in 1861 he was promoted to the superintendency. This post he held until 1872, when he was chosen to complete and organize the asylum at Athens, Ohio. This institution was opened in 1874, and he continued in office there until 1877, when he returned to the asylum at Columbus. "Political manipulations," says a contemporary, "caused a severance of his connection with this institution," and in June, 1878, he commenced his work at Spring Grove, where he continued until his death, which occurred in April last, in the 61st year of his age. He leaves eight children. Two are members of the medical profession; one - Miss Mattie Gundry -is matron of the Home for Feeble-Minded, Baltimore.

\section{MEDICO-PSYCHOLOGICAL ASSOCIATION OF GREAT BRITAIN AND IRELAND. \\ The anndal Meeting.}

The Fiftieth ANNUAL MEETING of the Association will be held on Thursday, July 23rd, 1891, at the City Asylum. Birmingham, nnder the Presidenoy of EduUnd BANks WhTtoombe, M.R.O.S.

Council Ment at 10 a.m.

General Memting at 11 a.m.

Afternoon Mreting (President's Adpress) at 2 p.m.

As this will be the JUBILEE Meeting it is hoped there will be a large attendance of members. The Dinner will probably take place at the Great Western Hotel.

Trains run from Snow Hill Station to Soho (G.W.R.), which is a fow minutes' walk from the Asylum. Dr. Whitcombe will arrange for some conveyances to bring Members to the Asylum from the Great Western Hotel at the hours of meeting of Care and Treatment Committee, the Council, and the Morning and Afternoon Meetings.

Fletoher Beath,

Darenth Asylum, Dartford,

How. Secretary. 